\title{
Primary immunosuppressive TNI-based conditioning regimens in pediatric patients treated with haploidentical hematopoietic cell transplantation
}

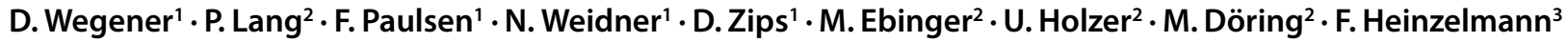

Received: 8 March 2021 / Accepted: 9 August 2021 / Published online: 2 September 2021

(c) The Author(s) 2021

\begin{abstract}
Purpose This retrospective analysis aims to address the toxicity and efficacy of a modified total nodal irradiation (TNI)-based conditioning regimen before haploidentical hematopoietic cell transplantation (HCT) in pediatric patients.

Materials and methods Patient data including long-term follow-up were evaluated of 7 pediatric patients with malignant $(n=2)$ and non-malignant diseases $(n=5)$ who were treated by a primary TNI-based conditioning regimen. TNI was performed using anterior/posterior opposing fields. All patients received $7 \mathrm{~Gy}$ single-dose TNI combined with systemic agents followed by an infusion of peripheral blood stem cells $(n=7)$. All children had haploidentical family donors.

Results Engraftment was reached in $6 / 7$ children after a median time of 9.5 days; 1 child had primary graft failure but was successfully reconditioned shortly thereafter. After an average follow-up time of 103.5 months (range 8.8-138.5 months), event-free (EFS) and overall survival (OS) rates were $71.4 \%$ and $85.7 \%$, respectively. One child with a non-malignant disease died 8.8 months after transplantation due to a relapse and a multiple organ failure. Follow-up data was available for 5/6 long-term survivors with a median follow-up (FU) of 106.2 months (range 54.5-138.5 months). Hypothyroidism and deficiency of sexual hormones was present in 3/5 patients each. Mean forced expiratory volume in $1 \mathrm{~s}$ (FEV1) after TNI was $71 \%$; mean vital capacity (VC) was $78 \%$. Growth failure ( $<10$ th percentile) occurred in $2 / 5$ patients (height) and $1 / 5$ patient (weight). No secondary malignancies were reported.

Conclusion In this group of patients, a primary single-dose $7 \mathrm{~Gy}$ TNI-based conditioning regimen before HCT in pediatric patients allowed sustained engraftment combined with a tolerable toxicity profile leading to long-term OS/EFS. Late toxicity after a median FU of over 9 years includes growth failure, manageable hormonal deficiencies, and acceptable decrease in lung function.
\end{abstract}

Keywords Primary conditioning $\cdot$ Total nodal irradiation $\cdot$ Engraftment $\cdot$ Toxicity $\cdot$ Raditherapy in pediatric patients

D. Wegener, MD

Daniel.Wegener@med.uni-tuebingen.de

Prof. P. Lang

Peter.Lang@med.uni-tuebingen.de

F. Paulsen, MD

Frank.Paulsen@med.uni-tuebingen.de

N. Weidner, MD

N.Weidner@med.uni-tuebingen.de

Prof. D. Zips

Daniel.Zips@med.uni-tuebingen.de

M. Ebinger, MD

Martin.Ebinger@med.uni-tuebingen.de
U. Holzer, MD

Ursula.Holzer@med.uni-tuebingen.de

M. Döring, MD

Michaela.Doering@med.uni-tuebingen.de

F. Heinzelmann, MD

f.heinzelmann@mvz-ke.de

1 Department of Radiation Oncology, University Clinic of Tuebingen, Tuebingen, Germany

2 Department of Paediatrics I, Hematology and Oncology, University Clinic of Tuebingen, Tuebingen, Germany

3 Department of Radiation Oncology, Clinic of Esslingen, Esslingen, Germany 


\section{Introduction}

Haploidentical hematopoietic cell transplantation (HCT) is a potentially curative treatment for several life-threatening malignant and benign hematological diseases [1]. The effect of non-myeloablative modified total nodal irradiation (TNI) to achieve immunosuppression and the feasibility and favorable outcome of TNI-based (re-)conditioning regimes have been described previously for both malignant and nonmalignant diseases [2-4]. However, long-term outcome and toxicity data are scarce in this high-risk population $[5,6]$ and a variety of TNI regimes are in use [7, 8]

This retrospective analysis aims to address the efficacy and toxicity of a 7 Gy single-dose TNI-based conditioning regimen before HCT on pediatric patients with various lifethreatening diseases.

\section{Materials and methods}

An analysis of 7 pediatric patients treated by a 7-Gy single-dose TNI conditioning regimen before primary HCT for various benign or malignant diseases (Tables 1 and 2) was performed. All patients were treated at the University Hospital of Tuebingen between 2006 and 2011. Regular follow-up (FU) examinations at the children's hospital were performed yearly over up to 10 years and these records were analyzed. The modified TNI technique consists of a supradiaphragmatic mantle field including the thymus and an infradiaphragmatic "inverted-y" field encompassing the spleen while shielding non-lymphoid tissues in the head, chest (e.g., lung), abdomen (e.g., kidneys and liver), and pelvis. This method was described in detail in a previous publication 2. All patients received TNI combined with systemic agents (Tables 1 and 2) followed by an infusion of peripheral blood stem cells $(n=7)$. All patients had haploidentical family donors. Grafts were depleted of $\mathrm{T}$ and $\mathrm{B}$ cells (cluster of differentiation 3 and 19 [CD3/CD19] depletion) in all pediatric patients with malignant and non-malignant diseases to mitigate (or reduce) the risk of graft vs. host disease (GVHD). Various GVHD prophylaxes were employed. Long-term immunosuppressive therapy had been administered in 5/7 patients before transplantation as a prior therapy. Neutrophil engraftment was defined as the first of three consecutive days of which the absolute neutrophil count was $>0.5 * 10^{9} / 1$. Toxicity was evaluated from posttreatment check-ups. Cardiac toxicity was assessed from pathological results in ECG or cardiac echo examinations. Thyroid toxicity, kidney toxicity, and hormonal status were defined by pathological blood parameters (TSH, fT3, fT4; creatinine/glomerular filtration rate; IGF-1, IGFBP-3; testosterone, LH, FSH). Lung toxicity was estimated by forced expiratory volume in $1 \mathrm{~s}$ (FEV1) and vital capacity (VC) at last examination. Growth and height are given in age- and gender-corrected percentiles.

\section{Statistical analysis}

Survival data for overall survival (OS), event-free survival (EFS), and non-relapse mortality (NRM) were calculated according to the Kaplan-Meier product limit method. Kaplan-Meier analyses were performed using Medcalc ${ }^{\circledR}$ (version 18.5, MedCalc Software, Ostend, Belgium). OS was defined as the time from HCT to death from any cause. EFS was defined as the time interval from the date of HCT to the date of relapse/progression of the underlying disease or death from any cause. NRM was defined as death from any cause without prior relapse or progression.

Table 1 Patient characteristics

\begin{tabular}{|c|c|c|c|}
\hline \multicolumn{4}{|l|}{ Disease } \\
\hline Malignant & \multicolumn{2}{|l|}{ Myelodysplastic syndrome } & $n=2$ \\
\hline \multirow[t]{4}{*}{ Benign } & \multicolumn{2}{|l|}{ Alpha-thalassemia } & $n=1$ \\
\hline & \multicolumn{2}{|l|}{ B-cell deficiency } & $n=1$ \\
\hline & \multicolumn{2}{|l|}{ Autoimmunogenic neutropenia } & $n=1$ \\
\hline & \multicolumn{2}{|l|}{ Aplastic anemia } & $n=2$ \\
\hline Immunosuppressive therapy prior to transplantation & \multicolumn{2}{|l|}{-} & $n=5$ \\
\hline Age at transplantation & \multicolumn{3}{|c|}{ Median 8.33 years (range $4.58-14.33$ years) } \\
\hline TNI regime & \multicolumn{2}{|l|}{$1 \times 7.0 \mathrm{~Gy}$} & $n=7$ \\
\hline \multirow[t]{2}{*}{ Therapeutic agents used for reconditioning: } & \multicolumn{2}{|c|}{ Fludarabine, melphalan, thiotepa, muromonab-CD3 } & $n=5$ \\
\hline & \multicolumn{2}{|c|}{ Fludarabine, melphalan, thiotepa, anti-thymocyte globulin } & $n=2$ \\
\hline \multirow[t]{3}{*}{ Cells transplanted per kg body weight (median, range) } & Mononuclear cells in $\times 10^{8}$ & $13.77(8.12-25.73)$ & $n=7$ \\
\hline & CD34+ progenitor cells in $\times 10^{6}$ & $17.34(6.06-28.22)$ & $n=7$ \\
\hline & $\mathrm{CD} 3+$ cells in $\times 10^{4}$ & $667.4(3.47-2953.46)$ & $n=7$ \\
\hline Engraftment & \multicolumn{3}{|l|}{$6 / 7$ patients } \\
\hline Time from TNI to engraftment & \multicolumn{3}{|l|}{ Median 9.5 days (range $9-10$ days) } \\
\hline
\end{tabular}

$T N I$ total nodal irradiation, $C D$ cluster of differentiation 
Table 2 Treatment characteristics by patient

\begin{tabular}{|c|c|c|c|c|}
\hline Disease & Sex & $\begin{array}{l}\text { Systemic agents for conditioning } \\
\text { (additional to } 7 \text { Gy TNI) }\end{array}$ & Dosage & Long-term therapy \\
\hline \multirow[t]{5}{*}{ Myelodysplastic syndrome } & \multirow[t]{5}{*}{$\mathrm{f}$} & Fludarabine & $5 \times 40 \mathrm{mg} / \mathrm{m}^{2}$ & Rituximab \\
\hline & & Melphalan & $1 \times 140 \mathrm{mg} / \mathrm{m}^{2}$ & Mycophenolate mofetil \\
\hline & & Thiotepa & $1 \times 10 \mathrm{mg} / \mathrm{kg}$ & Prednisolone \\
\hline & & Muromonab & $1 \times 0.01 \mathrm{mg} / \mathrm{kg}$ & \\
\hline & & Anti-thymocyte globulin & $2 \times 2 \mathrm{mg} / \mathrm{kg}$ & \\
\hline \multirow{5}{*}{$\begin{array}{l}\text { Severe combined immunodeficiency } \\
\text { with B cell deficiency and } \\
\text { hypogammaglobulinemia and alterations } \\
\text { in the } \mathrm{T} \text { cell spectrum }\end{array}$} & \multirow[t]{5}{*}{$\mathrm{f}$} & Fludarabine & $5 \times 40 \mathrm{mg} / \mathrm{m}^{2}$ & \multirow[t]{5}{*}{ Mycophenolate mofetil } \\
\hline & & Melphalan & $1 \times 140 \mathrm{mg} / \mathrm{m}^{2}$ & \\
\hline & & Thiotepa & $1 \times 10 \mathrm{mg} / \mathrm{kg}$ & \\
\hline & & Muromonab & $1 \times 0.01 \mathrm{mg} / \mathrm{kg}$ & \\
\hline & & Anti-thymocyte globulin & $2 \times 2 \mathrm{mg} / \mathrm{kg}$ & \\
\hline \multirow[t]{4}{*}{ Alpha-thalassemia } & \multirow[t]{4}{*}{$\mathrm{f}$} & Fludarabine & $4 \times 40 \mathrm{mg} / \mathrm{m}^{2}$ & \multirow{4}{*}{$\begin{array}{l}\text { Mycophenolate mofetil } \\
\text { Prednisolone }\end{array}$} \\
\hline & & Melphalan & $1 \times 70 \mathrm{mg} / \mathrm{m}^{2}$ & \\
\hline & & Thiotepa & $1 \times 10 \mathrm{mg} / \mathrm{kg}$ & \\
\hline & & Muromonab & $8 \times 0.1 \mathrm{mg} / \mathrm{kg}$ & \\
\hline \multirow[t]{4}{*}{ Autoimmunogenic neutropenia } & \multirow[t]{4}{*}{$\mathrm{f}$} & Fludarabine & $4 \times 40 \mathrm{mg} / \mathrm{m}^{2}$ & \multirow[t]{4}{*}{ Rituximab } \\
\hline & & Melphalan & $1 \times 70 \mathrm{mg} / \mathrm{m}^{2}$ & \\
\hline & & Thiotepa & $1 \times 10 \mathrm{mg} / \mathrm{kg}$ & \\
\hline & & Muromonab & $8 \times 0.1 \mathrm{mg} / \mathrm{kg}$ & \\
\hline \multirow[t]{5}{*}{ Aplastic anemia } & \multirow[t]{5}{*}{$\mathrm{f}$} & Fludarabine & $4 \times 40 \mathrm{mg} / \mathrm{m}^{2}$ & \multirow{5}{*}{$\begin{array}{l}\text { Mycophenolate mofetil } \\
\text { Prednisolone }\end{array}$} \\
\hline & & Melphalan & $2 \times 70 \mathrm{mg} / \mathrm{m}^{2}$ & \\
\hline & & Thiotepa & $1 \times 10 \mathrm{mg} / \mathrm{kg}$ & \\
\hline & & Muromonab & $26 \times 0.1 \mathrm{mg} / \mathrm{kg}$ & \\
\hline & & Prednisolone & $8 \times 4 \mathrm{mg} / \mathrm{kg}$ & \\
\hline \multirow[t]{4}{*}{ Aplastic anemia } & \multirow[t]{4}{*}{$\mathrm{f}$} & Fludarabine & $4 \times 40 \mathrm{mg} / \mathrm{m}^{2}$ & \\
\hline & & Melphalan & $2 \times 70 \mathrm{mg} / \mathrm{m}^{2}$ & \multirow{3}{*}{$\begin{array}{l}\text { Mycophenolate mofetil } \\
\text { Prednisolone }\end{array}$} \\
\hline & & Thiotepa & $1 \times 10 \mathrm{mg} / \mathrm{kg}$ & \\
\hline & & Anti-thymocyte globulin & $3 \times 5 \mathrm{mg} / \mathrm{kg}$ & \\
\hline \multirow[t]{5}{*}{ Myelodysplastic syndrome } & \multirow[t]{5}{*}{$\mathrm{m}$} & Fludarabine & $4 \times 40 \mathrm{mg} / \mathrm{m}^{2}$ & \multirow[t]{5}{*}{ Mycophenolate mofetil } \\
\hline & & Melphalan & $2 \times 70 \mathrm{mg} / \mathrm{m}^{2}$ & \\
\hline & & Thiotepa & $1 \times 10 \mathrm{~m} / \mathrm{kg}$ & \\
\hline & & Muromonab & $24 \times 0.1 \mathrm{mg} / \mathrm{kg}$ & \\
\hline & & Prednisolone & $7 \times 4 \mathrm{mg} / \mathrm{kg}$ & \\
\hline
\end{tabular}

TNI total nodal irradiation, $f$ female, $m$ male

\section{Results}

\section{Engraftment}

After a median follow-up time of 9.5 days, 6/7 children engrafted (range 9-10 days). One child had graft failure but successful re-transplantation 37 days after the first TNI including a $2 \times 2 \mathrm{~Gy}$ total body re-irradiation and was alive at last FU (LFU). Patient characteristics are given in Tables 1 and 2 .

\section{Survival outcome}

The average FU time was 103.5 months (range 8.8-138.5 months). At LFU, event-free (EFS) and overall survival
(OS) rates were $71.4 \%$ (standard error $17.1 \%$ ) and $85.7 \%$ (standard error 13.2\%), respectively. Kaplan-Meier graphs are shown in Fig. 1. Rates for 1-, 3-, and 5-year OS were $85.7 \%$ each. NRM did not occur in this cohort. Despite initial sustained engraftment, one child with a complex combined immunodeficiency with B cell deficiency (Table 1) died 8.8 months after transplantation due to a relapse and (re-)treatment-related septic multiple organ failure.

\section{Acute and long-term toxicity}

All patients had grade 1-2 mucositis and fever and several manageable infections occurred. Severe acute toxicity (grade $\geq 3$ CTCAE [9]) was reported in three children and consisted of mucositis $\mathrm{G} 3(n=2)$ and general dermatitis G4 

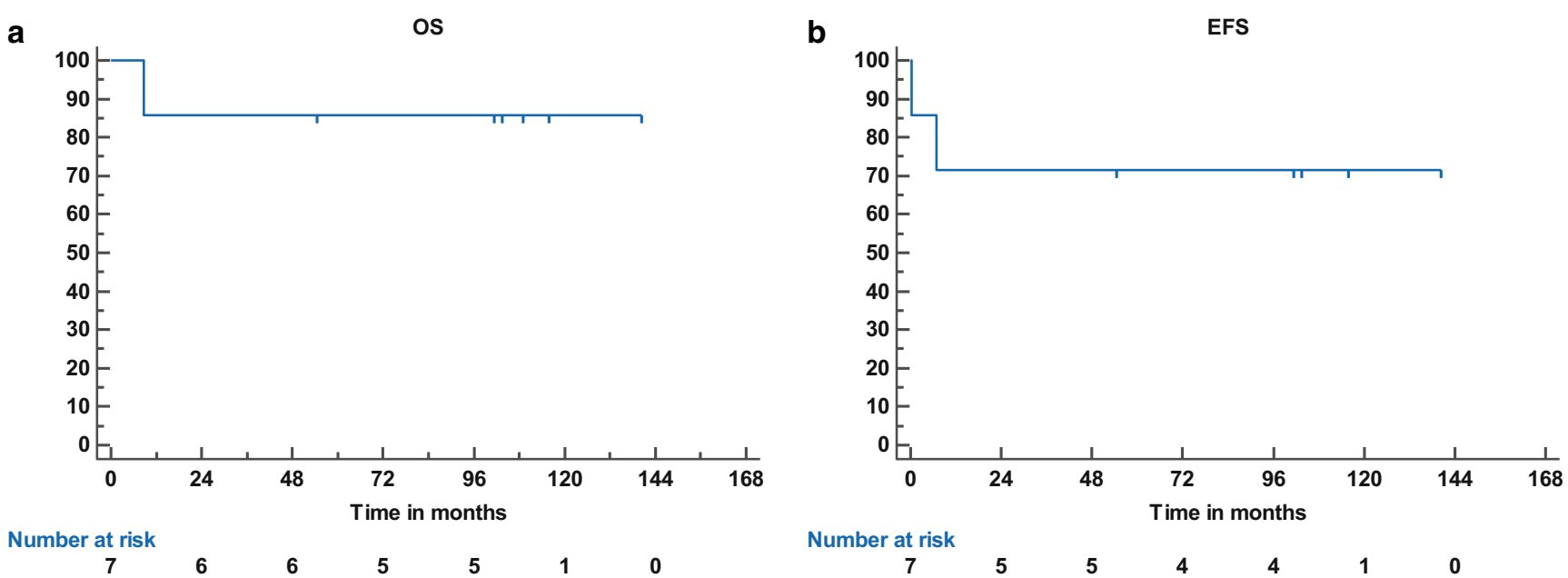

Fig. 1 Kaplan-Meier curves of the patient cohort. X-axis: time in months. Y-axis: survival probability. Number at risk given with each curve. a Overall survival $(O S)$ of the cohort. b Event-free survival $(E F S)$ of the cohort

$(n=1)$. In all cases, the patients recovered after cortisone treatment and phototherapy (dermatitis G4). No acute lung toxicity, no clinical signs of veno-occlusive disease, and no cardiac or neurotoxicity were detected.

FU data were available for 5/6 long-term survivors with a median FU of 106.2 months (range 54.5-138.5 months). One patient with aplastic anemia returned to her country of origin after the transplantation and could not be assessed for the evaluation of long-term toxicity. Results are shown in Tables 3 and 4. Hypothyroidism and insufficiency of sexual hormones was present in 3/5 patients each. Mean FEV1 after TNI was $71 \%$, mean VC was $78 \%$. No cardiac toxicity or chronic kidney failure occurred. Growth failure $(<10$ th percentile) was present in $2 / 5$ patients (height) and $1 / 5$ patient (weight). When compared to the growth and weight percentiles of each patient at the time of TNI, a mean decrease of -43 and -39 percentile points was found for growth and weight, respectively (Table 4). No secondary malignancies were reported in the surviving fraction with a median follow-up of 9.1 years (range 8.6-10.2 years).

\section{Discussion}

\section{Engraftment and survival outcome}

In this retrospective analysis of 7 pediatric patients undergoing single-dose 7 Gy TNI-based primary conditioning before allogeneic HCT, 6/7 children achieved sustained engraftment leading to long-term survival in this mixed cohort as evidenced by the stable OS and EFS plateaus reached after transplantation (OS $85.7 \%$ at LFU, median FU 9.1 years). Due to the lack of an identical sibling or unrelated donor, haploidentical HCT was performed, which is nowadays considered a standard of care conditioning regimen [10]. It is currently difficult to compare our longterm outcome results with previous published data due to small-sized series, heterogeneity of patients and underlying diseases, and different FU times. In adult patients with severe aplastic anemia treated similarly with 7.5-Gy singledose TNI and a conditioning regime containing ATG, Park et al. could demonstrate excellent engraftment (88/90 pa-

Table 3 Late toxicity after 7-Gy TNI-based conditioning

\begin{tabular}{lllll}
\hline Item & & $\begin{array}{l}\text { No. of patients with } \\
\text { available FU data }\end{array}$ & $\begin{array}{l}\text { Median FU (months, } \\
\text { range) }\end{array}$ & Pathological result $(n)$ \\
\hline Alive at LFU & $6 / 7$ & 5 & $106.2(54.5-138.5)$ & 1 patient with B cell deficiency died \\
Cardiac toxicity & ECG & 5 & $108.9(103.5-122.3)$ & 0 \\
& Cardiac echo & 5 & & 0 \\
Thyroid toxicity & & 5 & $108.9(103.5-122.3)$ & 3 (hypothyroidism, oral substitution) \\
$\begin{array}{l}\text { Renal toxicity } \\
\text { Hormonal status (other }\end{array}$ & 5 & $108.9(103.5-122.3)$ & 0 \\
than thyroid) & 5 & $108.9(103.5-122.3)$ & 3 (insufficiency of sexual hormones) \\
$\begin{array}{l}\text { Mean result (range) } \\
\text { Lung toxicity }\end{array}$ & & & & \\
& FEV1 $(\%)$ & 5 & $108.9(103.5-122.3)$ & $71.3 \%(66.3-77 \%)$ \\
\hline
\end{tabular}

$T N I$ total nodal irradiation, $F U$ follow up, $L F U$ last FU, $E C G$ electrocardiography, $F E V 1$ forced expiratory volume in $1 \mathrm{~s}, V C$ vital capacity 
Table 4 Further late toxicity after 7-Gy TNI-based conditioning at LFU

\begin{tabular}{|c|c|c|c|}
\hline Toxicity item & $\begin{array}{l}\text { Number of patients with } \\
\text { available data }\end{array}$ & Results & \\
\hline \multirow[t]{8}{*}{ Age-appropriate growth } & 5 & Weight $>$ P50 & $n=2$ \\
\hline & & Weight $<$ P50 & $n=2$ \\
\hline & & Weight $<$ P25 & $n=1$ \\
\hline & & Weight $<$ P3 & $n=0$ \\
\hline & & Height $>$ P50 & $n=0$ \\
\hline & & Height $<$ P50 & $n=1$ \\
\hline & & Height $<$ P25 & $n=3$ \\
\hline & & Height $<$ P3 & $n=1$ \\
\hline $\begin{array}{l}\text { Mean change in growth percentile from TNI to } \\
\text { LFU }^{\mathrm{a}}\end{array}$ & 5 & $\begin{array}{l}\text { Height }-43 \text { percentiles (range }-89 \text { to }+4 \text { ) } \\
\text { Weight }-39 \text { percentiles (range }-54 \text { to }-3 \text { ) }\end{array}$ & - \\
\hline Orthopedic toxicity & 5 & Slipped capital femoral epiphysis & $n=1$ \\
\hline Hypertonia & 5 & - & $n=2$ \\
\hline Neurologic/psychiatric toxicity & 5 & Depression & $n=1$ \\
\hline Other toxicity reported at LFU & 5 & Bilateral hearing impairment & $n=1$ \\
\hline Secondary malignancies & 6 & 0 & \\
\hline
\end{tabular}

TNI total nodal irradiation, $L F U$ last follow up, $P$ percentile, $n$ number of patients

${ }^{\text {a}}$ Percentiles calculated with age- and gender correction

tients) and survival rates (OS 100\%) after a median FU of 49.6 months [11]. Ocanto et al. report similar engraftment rates and low acute toxicity in an approach using fractionated total lymphatic irradiation in 25 pediatric patients with various malignant hematological diseases but did not report long-term follow-up [7].

\section{Toxicity}

Immunosuppressive approaches before transplantation such as the regimens in our study have been developed in order to enable crucial engraftment while reducing organ toxicity $[2$, 12-14], which is associated with the use of myeloablative conditioning regimens $[15,16]$. Of interest is the comparison of toxicity of TNI to regimens containing total body irradiation (TBI). Late effects of TBI can include interstitial pneumonitis in up to $30 \%$ of patients which can limit OS [17], veno-occlusive liver disease, cataracts in up to $50 \%$ of patients [18], hypothyroidism [19], chronic kidney insufficiency [20], and an increased risk for secondary malignancies $[7,15,17]$.

We are able to provide acute and late toxicity analyses with a median FU of 9.1 years of surviving patients. One patient died 8.8 months after HCT due to a relapse and the toxicity related to the systemic re-treatment. There is no evidence of a death related to the toxicity of a TNI procedure. Heart, kidney, and lung function parameters at LFU were at acceptable rates, not requiring treatment. Outcome and toxicity rates are in accordance with another cohort study of 33 retransplanted pediatric patients (malignant diseases $n=25$, benign $n=8$ ) having undergone 7-Gy TNI for reconditioning after graft failure [4] in our clinic. In both stud- ies, growth failure was a frequent and arguably the most relevant late toxicity, with a mean difference of -43 and -39 percentile points for growth and weight, respectively, between TNI and LFU. The high rates of growth failure compared to the literature of pediatric patients undergoing HCT is worrying [21] and might be related to the higher biologically effective 7-Gy single-dose treatment compared to fractionated regimes (2-Gy equivalent dose assuming an $\alpha / \beta$ of 4.5 Gy: $12.4 \mathrm{~Gy}$ ) [7, 22]. Yet this dose is still at the lower end of the spectrum which is known to cause stunting of vertebral growth and well within the recent recommendations of Hoeben et al. [23]. To differentiate between the influence of systemic therapies or TNI on growth, an analysis of length of bones within the TNI field (i.e., vertebrae) compared to lengths of extremities, which were not irradiated, might proof helpful. Of note, in the detailed examinations of the children's hospital, no visual discrepancy of this kind was mentioned for any patient. Additionally, the percentage of patients with hormonal insufficiencies hints towards a strong influence of growth hormone insufficiency on total growth. Yet no bone scans were available. Therefore, especially younger children might benefit from fractionated TNI regimens [23, 24]. In addition, modern radiation techniques (e.g., tomotherapy, IMRT) and/or fractionated TNI may lead to even lower rates of late toxicities [24, 25].

\section{Secondary malignancies}

Radiation therapy in children is justifiably considered to bear a high risk of secondary malignancies, especially in organs that are very sensitive to radiation exposure such as the thyroid, salivary gland, mammary gland, bone, and 
connective tissue [26, 27]. We focused particularly on this issue. Noteworthily, in this long-term study with a median follow-up of 9.1 years (range 4.5 to 11.5 years) and regularly performed detailed examinations, no secondary malignancies have yet been reported. However, since especially solid secondary malignancies are known to have latencies of several decades (e.g., breast cancer), lifelong clinical follow-up is recommended [28].

\section{Limitations}

Patient data were analyzed retrospectively and the study population is small and quite heterogeneous; therefore, outcome and toxicity data for a given entity cannot be predicted seriously. Further prospective, multicenter studies are desirable to identify the most promising conditioning regimen comparing single-dose versus fractionated TNI with chemotherapy and antibody-derived protocols, also considering the toxicity profile.

\section{Conclusion}

In this group of pediatric patients, single-dose 7-Gy TNIbased conditioning before allogenic hematopoietic cell transplantation allowed sustained engraftment combined with a tolerable toxicity profile leading to long-term OS/EFS. Late toxicity after a median LFU of over 9 years includes growth failure, manageable hormonal deficiencies, and acceptable decrease of lung function. No secondary malignancies were reported.

Funding This research did not receive any specific grant from funding agencies in the public, commercial, or not-for-profit sectors. The authors declare no conflict of interest. We mention the cooperation with Siemens Healthcare, Philips, Elekta, and PTB Braunschweig in another research project (DW, DZ).

Author Contribution Daniel Wegener and Frank Heinzelmann were involved in all aspects of planning, execution, data evaluation, and writing of the manuscript. Daniel Wegener performed the statistical analyses. All other coauthors were directly involved in data acquisition and drafting of the article and/or revising it critically and finally approved the version to be submitted.

Funding Open Access funding enabled and organized by Projekt DEAL.

Conflict of interest D. Wegener, P. Lang, F. Paulsen, N. Weidner, D. Zips, M. Ebinger, U. Holzer, M. Döring, and F. Heinzelmann declare that they have no competing interests.

Open Access This article is licensed under a Creative Commons Attribution 4.0 International License, which permits use, sharing, adaptation, distribution and reproduction in any medium or format, as long as you give appropriate credit to the original author(s) and the source, provide a link to the Creative Commons licence, and indicate if changes were made. The images or other third party material in this article are included in the article's Creative Commons licence, unless indicated otherwise in a credit line to the material. If material is not included in the article's Creative Commons licence and your intended use is not permitted by statutory regulation or exceeds the permitted use, you will need to obtain permission directly from the copyright holder. To view a copy of this licence, visit http://creativecommons.org/licenses/by/4. $0 /$.

\section{References}

1. Gyurkocza B, Gutman J, Nemecek ER, Bar M, Milano F, Ramakrishnan A, Scott B, Fang M, Wood B, Pagel JM, Baumgart J, Delaney C, Maziarz RT, Sandmaier BM, Estey EH, Appelbaum FR, Storer BE, Deeg HJ (2014) Treosulfan, fludarabine, and 2-Gy total body irradiation followed by allogeneic hematopoietic cell transplantation in patients with myelodysplastic syndrome and acute myeloid leukemia. Biol Blood Marrow Transplant 20(4):549-555. https://doi.org/10.1016/j.bbmt.2014.01.009

2. Heinzelmann F, Lang PJ, Ottinger H, Faul C, Bethge W, Handgretinger R, Bamberg M, Belka C (2008) Immunosuppressive total lymphoid irradiation-based reconditioning regimens enable engraftment after graft rejection or graft failure in patients treated with allogeneic hematopoietic stem cell transplantation. Int J Radiat Oncol Biol Phys 70(2):523-528. https://doi.org/10.1016/j.ijrobp.2007. 06.037

3. Kaplan HS (1981) Selective effects of total lymphoid irradiation (TLI) on the immune response. Transplant Proc 13(1):425-428

4. Wegener D, Lang P, Paulsen F, Weidner N, Zips D, Ebinger M, Holzer U, Döring M, Basu O, Gruhn B, Wittig A, Teltschik HM, Handgretinger R, Heinzelmann F (2019) Immunosuppressive total nodal irradiation-based reconditioning regimens after graft rejection or graft failure in pediatric patients treated with myeloablative allogeneic hematopoietic cell transplantation. Int $\mathbf{J}$ Radiat Oncol Biol Phys 104(1):137-143. https://doi.org/10.1016/j.ijrobp. 2018.12.031

5. Madden LM, Hayashi RJ, Chan KW, Pulsipher MA, Douglas D, Hale GA, Chaudhury S, Haut P, Kasow KA, Gilman AL, Murray LM, Shenoy S (2016) Long-term follow-up after reducedintensity conditioning and stem cell transplantation for childhood nonmalignant disorders. Biol Blood Marrow Transplant 22(8):1467-1472. https://doi.org/10.1016/j.bbmt.2016.04.025

6. Parsons SK, Phipps S, Sung L, Baker KS, Pulsipher MA, Ness KK (2012) NCI, NHLBI/PBMTC first international conference on late effects after pediatric hematopoietic cell transplantation: health-related quality of life, functional, and neurocognitive outcomes. Biol Blood Marrow Transplant 18(2):162-171. https://doi.org/10.1016/ j.bbmt.2011.12.501

7. Ocanto A, Escribano A, Glaría L, Rodríguez I, Ferrer C, Huertas C, Pérez A, Morera R (2020) TLI in pediatric patients. Clin Transl Oncol 22(6):884-891. https://doi.org/10.1007/s12094-019-022059

8. Paix A, Antoni D, Waissi W, Ledoux MP, Bilger K, Fornecker L, Noel G (2018) Total body irradiation in allogeneic bone marrow transplantation conditioning regimens: a review. Crit Rev Oncol Hematol 123:138-148. https://doi.org/10.1016/j.critrevonc.2018. 01.011

9. Trotti A, Colevas AD, Setser A, Rusch V, Jaques D, Budach V, Langer C, Murphy B, Cumberlin R, Coleman CN, Rubin P (2003) CTCAE v3.0: development of a comprehensive grading system for the adverse effects of cancer treatment. Semin Radiat Oncol 13(3):176-181. https://doi.org/10.1016/s1053-4296(03)00031-6

10. Saad A, de Lima M, Anand S, Bhatt VR, Bookout R, Chen G, Couriel D, Di Stasi A, El-Jawahri A, Giralt S, Gutman J, Ho V, Horwitz M, Hsu J, Juckett M, Kharfan-Dabaja MA, Loren A, Meade J, Mielcarek M, Moreira J, Nakamura R, Nieto Y, Roddy J, Satyanarayana G, Schroeder M, Tan CR, Tzachanis D, Burn J, Pluchino L 
(2020) Hematopoietic cell transplantation, version 2.2020, NCCN clinical practice guidelines in oncology. J Natl Compr Canc Netw 18(5):599-634. https://doi.org/10.6004/jnccn.2020.0021

11. Park SS, Min GJ, Park S, Lee SE, Yoon JH, Cho BS, Eom KS, Kim YJ, Lee S, Min CK, Kim HJ, Cho SG, Lee JW (2020) Excellent outcomes of hematopoietic stem cell transplantation with total nodal irradiation and antithymocyte globulin conditioning in severe aplastic anemia with advanced age and/or severe comorbidity. Bone Marrow Transplant 55(7):1447-1450. https://doi.org/10. 1038/s41409-019-0696-9

12. Slavin S, Naparstek E, Aker M, Cividalli G, Engelhard D, Hardan Y, Bromiker R, Brautbar C, Weshler Z, Or R (1989) The use of total lymphoid irradiation (TLI) for prevention of rejection of T-lymphocyte depleted bone marrow allografts in non-malignant hematological disorder. Transplant Proc 21(1):3053-3054

13. Zapatero A, Marin A, Lopez M, Martin De Vidales C, Cerezo L, Dominguez P, Perez Torrubia A (1996) Successful bone marrow transplantation in sensitized aplastic anemia patients using total lymphoid irradiation for conditioning: long-term follow-up. Hematol Oncol 14(4):165-172. https://doi.org/10.1002/(sici)10991069(199612)14:4〈165::aid-hon587)3.0.co;2-u

14. Gaziev D, Giardini C, Galimberti M, Lucarelli G, Angelucci E, Polchi P, Baronciani D, Erer B, Sotti G (1999) Bone marrow transplantation for transfused patients with severe aplastic anemia using cyclophosphamide and total lymphoid irradiation as conditioning therapy: long-term follow-up from a single center. Bone Marrow Transplant 24(3):253-257. https://doi.org/10.1038/sj.bmt.1701887

15. Stucki A, Leisenring W, Sandmaier BM, Sanders J, Anasetti C, Storb R (1998) Decreased rejection and improved survival of first and second marrow transplants for severe aplastic anemia (a 26year retrospective analysis). Blood 92(8):2742-2749

16. Abugideiri M, Nanda RH, Butker C, Zhang C, Kim S, Chiang KY, Butker E, Khan MK, Haight AE, Chen Z, Esiashvili N (2016) Factors influencing pulmonary toxicity in children undergoing allogeneic hematopoietic stem cell transplantation in the setting of total body irradiation-based myeloablative conditioning. Int J Radiat Oncol Biol Phys 94(2):349-359. https://doi.org/10.1016/j.ijrobp.2015. 10.054

17. Stoppel G, Eich HT, Matuschek C, Kortmann RD, Meyer F, Martinsson U, Nilsson K, Kristensen I, Vordermark D, Willich N, Christiansen H, Koch R, Steinmann D (2017) Lung toxicity after radiation in childhood: results of the international project on prospective analysis of radiotoxicity in childhood and adolescence. Radiother Oncol 125(2):286-292. https://doi.org/10.1016/j.radonc.2017. 09.026

18. Thomas O, Mahé M, Campion L, Bourdin S, Milpied N, Brunet G, Lisbona A, Le Mevel A, Moreau P, Harousseau J, Cuillière J (2001) Long-term complications of total body irradiation in adults. Int $\mathbf{J}$ Radiat Oncol Biol Phys 49(1):125-131. https://doi.org/10.1016/ s0360-3016(00)01373-0

19. Boulad F, Bromley M, Black P, Heller G, Sarafoglou K, Gillio A, Papadopoulos E, Sklar C (1995) Thyroid dysfunction following bone marrow transplantation using hyperfractionated radiation. Bone Marrow Transplant 15(1):71-76

20. Miralbell R, Bieri S, Mermillod B, Helg C, Sancho G, Pastoors B, Keller A, Kurtz JM, Chapuis B (1996) Renal toxicity after allogeneic bone marrow transplantation: the combined effects of total-body irradiation and graft-versus-host disease. J Clin Oncol 14(2):579-585. https://doi.org/10.1200/jco.1996.14.2.579

21. Löf CM, Winiarski J, Giesecke A, Ljungman P, Forinder U (2009) Health-related quality of life in adult survivors after paediatric alloSCT. Bone Marrow Transplant 43(6):461-468. https://doi.org/10. 1038/bmt.2008.338

22. Lowry L, Smith P, Qian W, Falk S, Benstead K, Illidge T, Linch D, Robinson M, Jack A, Hoskin P (2011) Reduced dose radiotherapy for local control in non-Hodgkin lymphoma: a randomised phase III trial. Radiother Oncol 100(1):86-92. https://doi.org/10.1016/j. radonc.2011.05.013

23. Hoeben BA, Carrie C, Timmermann B, Mandeville HC, Gandola L, Dieckmann K, Ramos Albiac M, Magelssen H, Lassen-Ramshad Y, Ondrová B, Ajithkumar T, Alapetite C, Balgobind BV, Bolle S, Cameron AL, Davila Fajardo R, Dietzsch S, Dumont Lecomte D, van den Heuvel-Eibrink MM, Kortmann RD, Laprie A, Melchior P, Padovani L, Rombi B, Scarzello G, Schwarz R, Seiersen K, Seravalli E, Thorp N, Whitfield GA, Boterberg T, Janssens GO (2019) Management of vertebral radiotherapy dose in paediatric patients with cancer: consensus recommendations from the SIOPE radiotherapy working group. Lancet Oncol 20(3):e155-e166. https://doi. org/10.1016/s1470-2045(19)30034-8

24. Lowsky R, Takahashi T, Liu YP, Dejbakhsh-Jones S, Grumet FC, Shizuru JA, Laport GG, Stockerl-Goldstein KE, Johnston LJ, Hoppe RT, Bloch DA, Blume KG, Negrin RS, Strober S (2005) Protective conditioning for acute graft-versus-host disease. N Engl J Med 353(13):1321-1331. https://doi.org/10.1056/NEJMoa050642

25. Schultheiss TE, Wong J, Liu A, Olivera G, Somlo G (2007) Imageguided total marrow and total lymphatic irradiation using helical tomotherapy. Int J Radiat Oncol Biol Phys 67(4):1259-1267. https:// doi.org/10.1016/j.ijrobp.2006.10.047

26. Pommier P, Sunyach MP, Pasteuris C, Frappaz D, Carrie C (2009) Second cancer after total-body irradiation (TBI) in childhood. Strahlenther Onkol 185(2):13-16. https://doi.org/10.1007/s00066009-1007-y

27. Socie G, Curtis RE, Deeg HJ, Sobocinski KA, Filipovich AH, Travis LB, Sullivan KM, Rowlings PA, Kingma DW, Banks PM, Travis WD, Witherspoon RP, Sanders J, Jaffe ES, Horowitz MM (2000) New malignant diseases after allogeneic marrow transplantation for childhood acute leukemia. J Clin Oncol 18(2):348-357. https://doi.org/10.1200/jco.2000.18.2.348

28. Coleman CN, Williams CJ, Flint A, Glatstein EJ, Rosenberg SA, Kaplan HS (1977) Hematologic neoplasia in patients treated for Hodgkin's disease. N Engl J Med 297(23):1249-1252. https://doi. org/10.1056/nejm197712082972303 